Andrew Ter Ern Loke*

\title{
On beginningless past, endless future, God, and singing angels: An assessment of the Morriston-Craig dialogue
}

DOI 10.1515/nzsth-2016-0004

Zusammenfassung: Ob die Vergangenheit oder die Zukunft unendlich sein kann, ist eine interessante Frage für theologisches Arbeiten an der Beziehung zwischen Gott und Zeit sowie der Eschatologie. In einem jüngst erfolgten Austausch ist Wes Morrison zu dem Schluss gekommen, dass wenn William Lane Craigs bekannte Argumentationskette gegen die Möglichkeit einer anfangslosen Serie von Ereignissen funktioniert, diese auch ebenso die Möglichkeit einer endlosen Serie von vorherbestimmten Ereignissen ausschließt. Er argumentiert, dass weder Craigs Behauptung, dass eine endlose Serie von Ereignissen potentiell unendlich ist, noch die Behauptung, dass zukünftige Ereignisse nicht existieren, diesen Schluss erfolgreich verhindern können. Ich behaupte, dass ein Befürworter des Kalam Arguments Craigs Verneinung einer aktuellen unendlichen Zahl von Sätzen nicht folgen muss, und ich zeige, wie Morristons Schluss verhindert werden kann. Im Einzelnen argumentiere ich, dass eine asymmetrische Behandlung der Vergangenheit und der Zukunft gerechtfertigt ist durch eine dynamische Theorie der Zeit, während die Unterscheidung zwischen abstrakten und konkreten Unendlichkeiten hilfreich ist, um auf Morristons Gegenargument, das auf einer Zahl von noch zu sagenden Lob der Engel basiert, zu antworten.

Schlüsselwörter: Gott und Zeit, Eschatologie, Kalam Kosmologisches Argument, Platonismus

Summary: Whether the past or future can be infinite is an interesting question for theologians working on the relationship between God and Time as well as Eschatology. In a recent exchange, Wes Morriston concluded that if William Lane Craig's familiar line of argument against the possibility of a beginningless series of events worked, it would work just as well against the possibility of an endless series of predetermined events. He argued that neither Craig's claim that an endless series of events is potential infinite nor the claim that future events don't exist is successful in blocking this conclusion. I argue that a proponent of

\footnotetext{
*Korrespondenzautor: Andrew Ter Ern Loke, Faith and Global Engagement, The University of Hong Kong, Room 1001, 10 / F, Run Run Shaw Tower, Centennial Campus, HK-Pokfulam Road, E-Mail: andyloke@hku.hk
} 
the Kalam Argument does not have to follow Craig's denial of an actual infinite number of propositions, and I show how Morriston's conclusion can be blocked. In particular, I argue that an asymmetric treatment of past and future is justified on a dynamic theory of time, while the distinction between abstract and concrete infinities is helpful for responding to Morriston's counter-argument based on the number of angelic praises yet-to-be-said.

Keywords: God and Time, Eschatology, Kalam Cosmological Argument, Platonism

\section{Introduction}

Can the past or future be infinite? This question is of interest to theologians working on the relationship between God and Time as well as Eschatology, and it is the subject of a recent exchange between philosophers of religion Wes Morriston and William Lane Craig. ${ }^{1}$ The dispute between Morriston and Craig concerns Craig's asymmetric treatment of the past and the future. Craig argued that, while the future may be infinite, the past must be finite. Morriston objected that if Craig's argument against the possibility of the actual infinite based on paradoxical implications (as illustrated by Hilbert's Hotel) worked as advertised, it would not only rule out a beginningless series of past events as Craig intended, it would also rule out an endless series of pre-determined events, which seems inconsistent with Christian Eschatology. Craig replied by clarifying that an infinite future is possible, but only in the sense that it is potentially infinite; whereas an infinite past is impossible because the past cannot be a potentially infinite.

The distinction between actual infinite and potential infinite is important here: An actual infinite is conceived as a determinate whole actually possessing an infinite number of members, in contrast with a potential infinite which never actually attains infinity, although it increases perpetually towards infinity as a limit. At any point in time a potential infinite is actually finite. ${ }^{2}$ The crucial

1 Wes Morriston, “Beginningless Past, Endless Future, and the Actual Infinite," Faith and Philosophy 27 (2010): 439-450; William Lane CRAIG, “Taking Tense Seriously in Differentiating Past and Future: A Response to Wes Morriston,” Faith and Philosophy 27 (2010): 451-6; Wes MorRiston, "Beginningless Past and Endless Future: Reply to CRAIG," Faith and Philosophy (forthcoming), available at http://spot.colorado.edu/ morristo/reply2CRAIG-forthcoming.html.

2 William Lane Craig and James Sinclair, "The Kalam Cosmological Argument," in The Blackwell Companion to Natural Theology, ed. William Lane CRAIG and J. P. Moreland (Oxford: Blackwell, 2009), 103-105. CRAIG explains that because set theory with its definite and distinct elements does not utilize the notion of potential infinity, a set containing a potentially infinite number of members is impossible, indeed no set could capture the essentially dynamic character 
point is Craig's idea that the future can be potentially infinite whereas the past cannot, and this justifies his asymmetric treatment of the past and the future. I shall explain Craig's idea in what follows:

When we ask for the causes of the existence of the stars, as well as the causes of the causes of their existence, we are asking for causes which actually existed, we are not asking for causes which potentially existed. Likewise, the events that led to the formation of our sun, for example, have already happened, that is, they have already been actualized, and their number is no longer increasing perpetually but a determinate whole. Hence, when we ask whether there could be an infinite regress of causes or events or changes or intervals of time, we are asking whether there could be an actual infinite regress, and not whether there could be potential infinite regress, for given that the number of (say) events in the past of any event is a determinate whole it cannot be a potential infinite. The past is either actual infinite or actual finite.

The number of events in the future of any event, however, can be a potential infinite if one embraces a dynamic (A-) theory of time. According to this theory, the members of a series of events come to be one after another, and the number of events which have happened would be increasing perpetually if the future is unending (although the number of events which have happened prior to any actual event(s), say the formation of our sun, would not be increasing perpetually but is a determinate whole, as noted above). By contrast, according to a static [B-] theory of time, the members of a series of events do not come to be one after another, rather the series of events is a tenselessly existing manifold all of whose members (including future events) are equally real. On a static theory of time, the future cannot be a potential infinite; it would be either finite or actually infinite.

In short, the number of events lying in the future of any event can be a potential infinite depending on what theory of time one adopts and whether the future is unending, but the number of events lying in the past of any event cannot be a potential infinite in any case, because the past does not contain any potential events that have not been actualised. Craig has argued that paradoxes such as Hilbert's Hotel show that actual infinities cannot exist, and therefore neither the past nor the future

of potential infinite. Such a collection would be one in which the membership is not definite in number but may be increased without limit. It would best be described as indefinite (ibid). Against Oppy's tenseless characterizations of potential infinite (Graham OPPY, Philosophical Perspectives on Infinity [New York: Cambridge University Press, 2006], 261-4; cf. 244-5), CRAIG observes that a major shortcoming of these characterizations is that they are incapable of handling views of time which regard tense and temporal becoming as objective features of reality and, hence, worlds in which the future is potentially infinite in the sense of growing toward infinity as a limit. See William Lane CRAIG, "Review of Philosophical Perspectives on Infinity, by Graham Oppy,” Philosophia Christi 10 (2008): 201-208. 
can be actual infinite. Nevertheless, as a proponent of the dynamic theory of time, Craig thinks that the future can be potentially infinite whereas the past cannot. ${ }^{3}$

Let us now discuss in greater detail the arguments of Morriston and Craig's replies. Morriston proposed a thought experiment featuring a pair of angels to illustrate his point:

'Suppose that God has just decreed that Gabriel and Uriel will take turns praising Him for one minute of celestial time, and that they will do so forever. Gabriel will do the odd-numbered praises and Uriel the even-numbered ones. Let's go a step further. So as not to leave any opportunity for Gabriel or Uriel to mess things up, let's suppose that this is no mere instruction or recommendation, but that God has exercised His supreme power in such a way as to make it the case that each praise in the endless series of praises we have envisaged will occur. Each of them is discrete, wholly determinate, and certain to occur because God has determined that it will occur... If you ask, "How many distinct praises will be said?' the only sensible answer is, 'Infinitely many."

Morriston asserted that a scenario like the above is surely possible given the assumptions widely shared by theists. Observing that Craig's argument against the possibility of the actual infinite based on paradoxical implications has been offered in support of the premise of the Kalam Cosmological Argument that the universe began to exist, Morriston claimed that he can derive the same sorts of allegedly absurd implications that friends of the Kalam argument claim to be able to derive from a beginningless series of events, as follows:

'God could instead have determined that Gabriel and Uriel will wait a celestial minute after each pair of praises, thus making 'room' for infinitely many more praises by a third angel - Raphael, say. Infinitely many praises by Raphael are 'added,' and the praises of all three angelic beings will be said in the same (infinite) amount of time. That's absurd...God could instead have determined that Gabriel and Uriel will stop after praise number four. Infinitely many praises would be prevented, and the number of their future praises would be only four. Alternatively, God could have determined that Gabriel be silent during all the celestial minutes between Uriel's future praises. In this case too, infinitely many praises would be prevented, but the number of future praises would instead be infinite. That shows that your infinite future praise scenario has inconsistent implications. ${ }^{5}$

3 In a recent article, Landon Hedrick objects that the 'Hilbert's Hotel Argument' (HHA) is ineffective against proponents of presentism, which includes CRAIG himself, but I have replied that it is very easy to modify HHA such that it addresses Hedrick's objection. See Landon HEDRICK, “Heartbreak at Hilbert's Hotel,” Religious Studies, 50 (2014): 27-46; Andrew LoKE, "No Heartbreak at Hilbert's Hotel: a Reply to Landon Hedrick," Religious Studies 50 (2014): 47-50.

4 Morriston, “Beginningless Past, Endless Future” (see above, n.1), 443.

5 Ibid, 444. 
Morriston concluded that if the theist does not think that these implications show that the endless series of predetermined events featured in the scenario is impossible, then neither should they agree with Craig that the allegedly absurd implications of a beginningless series of past events show that a beginningless series is impossible.

In his reply to Morriston, Craig argued that, on an dynamic (A-) theory of time, the series of praises that will be said by either (or both) of the angels in Morriston's scenario is merely potentially infinite. Craig argued that it is 'composed of a finite but ever increasing number of events with infinity as a limit...So with respect to Morriston's illustration of two angels who begin to praise God forever, an A-theorist will concur whole-heartedly with his statement, 'If you ask, 'How many praises will be said?' the only sensible answer is, infinitely many' - that is to say, potentially infinitely many. If this answer is allowed the A-theorist, then Morriston's allegedly parallel arguments collapse. ${ }^{6}$

Craig then argued that Morriston's proposal that one can derive the same sorts of allegedly absurd implications would not work, because in Morriston's scenario the infinity involved is merely potential and the number of praises said by the angels will always be finite. Craig explained, 'God could have made room for potentially infinitely many more praises by a third angel, in which case potentially infinitely many praises are 'added,' and the praises of all three angels will be sung in the same potentially infinite amount of time. No absurdity there, for the number of praises said by the angels will always be finite, even though increasing toward infinity as a limit. Or again, if God determined that the angels stop after the fourth praise or if one angel were silenced, potentially infinitely many praises would be prevented, but in one case only four praises will be said while in the other potentially infinitely many will be said. Again, there is no absurdity, since the infinity is merely potential. Nothing parallel can be said of a beginningless series of events, for given the asymmetry of temporal becoming the past cannot be potentially infinite, for then it would have to be finite but growing in a backwards direction. ${ }^{7}$

Craig went on to argue, among other things, that Morriston's suggestion that we consider future-tensed truths or corresponding tensed facts (rather than future events, which on an A-Theory of time are not part of reality) 'makes two unjustified assumptions: first, Platonism with respect to propositions and, second, the actual infinitude of propositions or facts.' Craig proposed that 'The finitist will therefore either deny Platonism with respect to propositions, taking them to be useful fictions perhaps, or deny that there are an infinite number of propositions,

6 CRAIG, “Taking Tense Seriously” (see above, n. 1), 452.

7 Ibid, Section II. 
since, God's knowledge being non-propositional, propositions are the byproduct of human intellection and so merely potentially infinite in number, as we come to express propositionally what God knows in a non-propositional way."

Morriston, however, is not satisfied with Craig's reply. In his most recent response, Morriston writes, 'Craig is certainly right about one thing. The number of praises that have been said by the angels in my scenario will always be finite. Right now, the number is zero. Once the praising has begun, the collection of praises that have been said will increase without limit (or, as Craig prefers, 'toward infinity as a limit'). But I was not asking for the number of praises that have been said. Instead, I was asking for the number of praises yet-to-be-said - that is, for the number of praises, each of which will eventually be said. In the world of my thought experiment, the series of praises yet-to-be-said is not growing, is never finite, and does not satisfy Craig's definition of "potentially infinite."'

Morriston notes that Craig did answer the question, 'What is the number of praises in the series of future praises?', and that Craig's answer was 'None. ${ }^{10}$ Morriston also notes that on Craig's presentist ontology future events do not exist, and that Craig had argued that, unlike past events, future events have not been actualized. Nevertheless, Morriston thinks that Craig's reply does not escape from the fact that in his scenario each of the future praises is pre-determined in such a way that it cannot fail to be actualized. He argues that in his scenario, it must be true that:

G. For every odd number $n$, Gabriel will (eventually) have said the $n$th praise in the series of praises that have been said.

U. For every even number $n$, Uriel will (eventually) have said the $n$th praise in the series of praises that have been said.

From this, Morriston concludes that, "even if "there are" no future events, there is still a one-to-one correspondence between the natural numbers and the tensed truths in various relevant series. ${ }^{11}$

Morriston goes on to argue, among other things, that Craig's point concerning Platonism with respect to propositions is irrelevant ('I do not think I need to take a stand for or against Platonism'), and reaffirms his original conclusion that an endless series of pre-determined praises will have the paradoxical implications that Craig finds so absurd. 'In this respect, an endless series (of pre-determined events) is on the same footing as a beginningless one. ${ }^{, 12}$

8 Ibid, 454.

9 Morriston, "Beginningless Past and Endless Future” (see above, n. 1), 3.

10 Craig, "Taking Tense Seriously" (see above, n. 1), 444-5.

11 Morriston, "Beginningless Past and Endless Future” (see above, n. 1), 6.

12 Ibid, 12. 


\section{Assessment}

In assessment of the exchange between Craig and Morriston, I shall argue that, contrary to Craig and Morriston, the issue about abstract objects is not a 'sideshow', but rather it is of importance for addressing Morriston's counter-argument based on the number of praises yet-to-be-said. With regards to this point, Craig's response that the number of praises that-will-be-said is a potential infinite is inadequate, for Morriston is not asking about the praises that-will-be-said, but rather the praises yet-to-be-said, the series of which, Morriston argues, is not growing, is never finite, and does not satisfy Craig's definition of potentially infinite, as noted above. Craig's main point in reply to Morriston was about the praises that-will-besaid, not the praises yet-to-be-said, and thus he misses the thrust of Morriston's counter-argument. In what follows, I shall (unlike Craig) focus on 'the praises yet-to-be-said'.

In response to Morriston's counter-argument, it seems that proponents of the Kalam Cosmological Argument do not have to follow Craig's proposal to either deny Platonism with respect to propositions or deny that there are an infinite number of propositions. ${ }^{13}$ Rather, they can hold the view that the argument against the possibility of the actual infinite based on paradoxical implications is directed against the existence and actualization of an actual infinite number of concrete entities or events; it is not directed against the existence of an actual infinite number of abstract entities. This move has been made, for example, by J. P. Moreland, who suggests that the problematic nature of paradoxes such as Hilbert's Hotel seems to be related to the fact that (1) the members of the set are finite, located, moveable entities, which opens up the possibility of adding, subtracting, or rearranging the members of the set, and (2) the members of the set are spatially extended. Since abstract entities are not finite, located, moveable entities nor spatially extended, the argument against the possibility of the actual infinite based on paradoxes such as Hilbert's Hotel does not apply to them. ${ }^{14}$ I would advance Moreland's view by proposing that the problematic nature of paradoxes such as Hilbert's Hotel seems to be related to the fact that the members of the set have causal powers and are embedded in a network of

13 Elsewhere, CRAIG has argued that abstract entities do not exist, but others have responded to his views. See the discussion between CRAIG and others in Paul Gould (ed.), Beyond the Control of God?: Six Views on the Problem of God and Abstract Objects (London: Bloomsbury, 2014). See also Andrew LoKE, “On the infinite God objection: a reply to Jacobus Erasmus and Anne Hendrik Verhoef” (forthcoming).

14 J. P. Moreland, "A response to a Platonistic and to a set-theoretic objection to the Kalām cosmological argument,” Religious Studies, 39 (2003), 379. 
causal relations (hence they could be moved around). Since abstract entities do not have causal powers and are not embedded in a network of causal relations in the relevant sense, ${ }^{15}$ the argument against the possibility of the actual infinite based on paradoxes such as Hilbert's Hotel does not apply to them.

By making this sort of moves, proponents of the Kalam Cosmological Argument can accept Platonism and also allow for an actual infinite number of abstract entities, including propositions. They can claim that distinguishing between abstract infinities and concrete infinities is of great importance. After all, mathematicians play around with abstract infinities all the time. For example, if an infinite number of members are removed from an infinite set, one can get a null set, but one can also get other sets too, depending on how the members are removed. It is because of metaphysical problems related to this - as illustrated by the 'absurdities' of Hilbert's hotel, for example - that proponents of the Kalam argument think that abstract infinities cannot be instantiated in the concrete world. Nevertheless, as long as the problems remain in the abstract, that is fine, and mathematicians (as well as philosophers such as Morriston) can continue to play around with them.

Having made the point that argument against the possibility of the actual infinite based on paradoxical implications is directed against concrete rather than abstract entities, the proponent of the Kalam argument can reply to Morriston as follows: The number of praises yet-to-be-said - that is, the number of praises, each of which will eventually be said - is actual infinite, but the number of praises yet-to-be-said do not yet exist as concrete entities or events. Neither would it ever be the case that all of them have been actualised as concrete entities or events, for no matter how many praises have been said, an angel could still say one more. As noted earlier, Morriston agrees that 'the number of praises that have been said by the angels in my scenario will always be finite,' and that 'the collection of praises that have been said will increase without limit.' One might think it absurd that an actual infinite number of praises will never be said even though each of the praises will eventually be said, but given that 'the praises that will eventually be said' do not yet exist as concrete entities or events, this is a problem that remains in the abstract and does not cause problem in the concrete world.

While it is true that in Morriston's scenario each of the future praises is pre-determined in such a way that it will eventually be actualized, i.e. while it is true that ' $(G)$ for every odd number $n$, Gabriel will (eventually) have said the $n$th praise in the series of praises that have been said' and '(U) for every even number $n$, Uriel will (eventually) have said the $n$th praise in the series of praises

15 As Graham Oppy, a friend of infinity, notes. See OPPy (see above, n.2), 242. 
that have been said', nevertheless there will never be a time at which all of the future praises are or have been said, and hence never a time at which there is or have been an actual infinite of concrete entities or events. Morriston claims that there is still a one-to-one correspondence between the natural numbers and the tensed truths in various relevant series. However 'tensed truths' are abstract rather than concrete entities.

With respect to God's knowledge of the number of praises that will be spoken, Morriston notes that Craig has suggested that God knows the whole of reality (including the future) by way of a single, indivisible intuition. Morriston objects that this tells us nothing about how he knows the future. ${ }^{16}$ In reply, the fact that Craig has not explained the mechanism by which God knows the future does not imply that his suggestion is false. On the contrary, given the limitation of human cognition we should not be surprised that we have not figured out the divine mechanism by which God knows things, or that we could not do so. Hence Morriston's objection is not an adequate reason for rejecting Craig's suggestion. Morriston also objects that Craig's suggestion does not solve the problem at hand. Morriston claims that as long as propositions (G) and (U) are true - as long as each of them would, if abstracted from the object of God's 'undivided intuition,' have the same standing as Mars has two moons - it will be easy to do the counterfactual variations on his imaginary angelic praise scenario that drive his original argument. ${ }^{17}$ In reply, Morriston seems to have failed to observe that the truths of these propositions abstracted from the object of God's 'undivided intuition' remain as abstract entities, and that unlike the two moons of Mars which exist as concrete entities the number of praises yet-to-be-said do not exist as concrete entities.

In his earlier paper Morriston pre-empted that Craig might perhaps require that the members of the collection be concrete rather than abstract, but he claimed that one can still derive the same sorts of allegedly absurd implications that friends of the Kalam argument claim to be able to derive from a beginningless series of events, and thus in the present context this is a matter of no consequence. ${ }^{18}$ However, as noted above it has been shown in Craig's reply that one cannot derive the same sorts of allegedly absurd implications where actual events are concerned. The underlying reason is that in Morriston's scenario the infinity of actual events (i. e. praises said by the angels) involved is merely potential and the number of events that happen will always be finite. There will never be a time at which infinitely many praises by Raphael have been said and are actually 'added'

16 Morriston, “Beginningless Past and Endless Future” (see above, n. 1), 10-11.

17 Ibid, 11-12.

18 Morriston, “Beginningless Past, Endless Future” (see above, n. 1), 449-450. 
to the praises said, and while the number of praises yet-to-be-said by Raphael is actual infinite, these do not exist as concrete entities or events, nor would it ever be the case that all of them have been actualised as such. The problem that 'infinitely many praises by Raphael are added and the praises of all three angelic beings will be said in the same (infinite) amount of time' remains in the abstract, and hence they do not cause problems in the concrete world. Again, there will never be a time at which infinitely many said praises would have been prevented, for example, by God determining that Gabriel and Uriel stop after praise number four or that Gabriel be silent during all the celestial minutes between Uriel's future praises. While the number of praises yet-to-be-said and prevented is actual infinite, they do not exist as concrete entities or events. Once again, the problem remains in the abstract; they do not cause problems in the concrete world. On the other hand, the implications that friends of the Kalam argument claim to be able to derive from a beginningless series of events concern actual events that have happened, and which would cause problems in the concrete world. Therefore, the claim that one can derive the same sorts of allegedly absurd implications is false, and hence it is not an adequate justification for thinking that 'the requirement that the members of the collection be concrete rather than abstract' is a matter of no consequence.

\section{Conclusion}

In conclusion, a proponent of the Kalam Cosmological Argument can reply to Morriston by saying that that the argument against the possibility of the actual infinite based on paradoxical implications is directed against the existence and actualization of an actual infinite number of concrete entities and events rather than against the existence of abstract entities. The number of praises yet-to-besaid is actual infinite, but they do not exist as concrete entities or events, and there will never be a time at which all of them are or have been actualised as concrete entities or events. Therefore in the endless future series we will not have the paradoxical implications that Craig finds absurd. On the other hand, if the series of praises is beginningless, there would have been the actualization of an actual infinite number of events, that is, there would have been an actual infinite number of praises spoken, and we will have the paradoxical implications that Craig finds absurd. Hence, contrary to Morriston, an endless future series of pre-determined events and a beginningless series are not in the same boat. There cannot be a beginningless past, but there can be an endless future in which angels and humans sing the praises of God forever. 
Copyright of Neue Zeitschrift für Systematische Theologie und Religionsphilosophie is the property of De Gruyter and its content may not be copied or emailed to multiple sites or posted to a listserv without the copyright holder's express written permission. However, users may print, download, or email articles for individual use. 